\title{
Relationship between self-control and peer conformity with smoking behavior
}

\author{
Fauzan $^{1}$, Firman ${ }^{2}$, Daharnis ${ }^{3}$ \\ ${ }^{123}$ Universitas Negeri Padang, Padang - Indonesia, (ffauzan50@gmail.com)
}

\begin{abstract}
This research based on students of smoking behavior that unusual, smoking behavior is perceived as self-identity. However, students at senior high school level have great potential to be addicted to cigarettes.The low ability students in self-control and strength of peer conformity is the most dominant factor in influencing the smoking behavior of students. This study aims to describe self-control, peer conformity, smoking behavior, and the relationship of self-control andpeers conformity with smoking behavior. This research used quantitative approach with descriptive-correlational method. The subjects of this research were students which consume cigarette consists of 124 people. The instrument of the research, for all three variables was a Likert scale model, with instrument reliability:self-control 0.922 , peers conformity 0.847 , and smoking behavior 0.951 . The data were analyzed by using multiple regression. The results shows that there was significant relationship between of self-control and peer conformity with smoking behavior.
\end{abstract}

Keywords: self control, peer conformity, smoking behavior

\section{Introduction}

Smoking behavior has been transformed into a serious problem, marked by the increasingly young age of starting to smoke, generally begins when adolescence. Smoking is one of the products that are easy to get into the teen world for free cigarette sales, this resulted in increased cigarette consumption among adolescents. Results Health Research showed an increase prevalence smokers aged 15 years and over, in 2007 amounted to 36.3\%, in 2010 43.3\%, and in 2013 amounted to 55.4\%, especially teenagers who were in the Senior Secondary School, generally aged 16-19 years. Data from the Ministry of Health in 2014 showed that teenage smoking prevalence increased 3 times from 7:15 in 1995 to $20.5 \%$ in 2014.

Based on data collection of students who consume cigarettes, the sheer number of 171 male students found 124 students who consume cigarettes. Cigarette consumption among young people is feared to be a habit that is difficult to remove, so it gives a bad impact on adolescent development. Smoking was originally an attempt to escape from fear, anxiety or other psychological issues. Later, it became a habit because by eating cigarettes teenagers find pleasure. Other factors that cause teenagers start smoking is a desire to try cigarettes, follow peers, and want to be seen as an adult 
(Kurniafitri, D., \& Asriwandari, H. 2015; Lubis, E. E. 2015; Wulaningsih, R., \& Hartini, N. 2015; Faridah, F. 2015).

Adolescence is a period of transition to adulthood, teenagers usually begin to focus on the behavior associated with adult status, without considering the positive and negative effects of such behavior. This happens because adolescence is a time search for identity so that adolescents have difficulty controlling themselves to direct behavior. Adolescence is a period in which the adolescent search for identity in a continuum between identity and identity confusion(Yusuf, 2004; Beyers, W., \& Luyckx, K. 2016).

In the transitional period is usually teenagers are not able to control impulses within him, so that adolescents are particularly vulnerable were swept away and the style of life is not good one smoking behavior. In this situation, the role of self-control is needed to assist in organizing and directing the behavior of adolescents. Factors that influence smoking behavior, one of which is self-control, because the self-control are aspects of behavioral control in which individuals can manage any negative impulses from the inner to the distribution of encouragement toward positive(Ajzen, 2007; Runtukahu, G. C., Sinolungan, J., \& Opod, H. 2015).

Smoking behavior allegedly in line with the increasing influence of the peer group. Peers cannot be separated from the life of a teenager, even view their peers about the behavior displayed is an important part of youth. Some teens usually will make various efforts to be included as members of the group. The strong stimulus from the peer group allows changes in adolescent behavior in a way equating behavior by associating group (conformity) (Monks, 2004; Hidayati, N. W. 2016).

Conformity allows individuals to emulate the attitude or behavior of others, it can certainly provide a positive or negative impact. Associated with conformity peers, the appearance of conformity in adolescents also can contribute positively or negatively. Conformity is categorized into two forms of acceptance and compliance (Kurniawan, S., \& Rois, A. M. M. 2009; Priantoro, A. 2011; Saputro, B. M., \& Soeharto, T. N. E. D. 2012).

Acceptance is a form of conformity by individuals by way of equating attitudes, personal beliefs, and behavior in front of the public with the norm or pressure of the group. Meanwhile, Compliance is a form of conformity by individuals in how to behave according to the pressure group, while personally do not approve of such behavior (Suryawati \& Marwati, 2006; Yulfitri, F., Marjohan, M., \& Sano, A. 2014).

Based on the above description, it can be assumed that the tendency of the smoking behavior of students influenced by the self-control and conformity peers. The assumption of self-control is visible from the inability in controlling student behavior and a lack of consideration before taking a decision. While the strength of conformity peers seen from a tendency of students to express themselves with peers.

The smoking behavior of students in need of concrete handling of the school, particularly teachers of guidance and counseling. Students need proper and accurate service to set standards of behavior. The possibility of poor students ' ability in controlling themselves and powerful peer conformity it is essential to be traced in greater depth, associated with the advent of the smoking behavior of students. As for research purposes to be achieved in these studies as follows: 1) Describe self-control 2) Describe conformity peers, 3) Describe the behavior of smoke 4) tested the relationship of selfcontrol and conformity peers with the smoking behavior of students.

\section{Methods}

This research used quantitative approach with descriptive-correlational method. The subjects of this research were students whichconsume cigarette consists of 124 people.Data collection tool that is 
used in the form of a questionnaire Likert scale model.instrument reliability: self-control 0.922 , peers conformity 0.847 , and smoking behavior 0.951 .

\section{Results and Discussion}

The data in this study include self-control variable (X1), conformity peers (X2), and smoking behavior (Y). Here's a description of the research data are depicted with an average classification: very high category $\geq 84 \%$, $66-83 \%$ higher category, the category was $52-67 \%, 36-51 \%$ lower category, and the category of very low $\leq 35 \%$.

\section{Self-Control $\left(\mathrm{X}_{1}\right)$}

Most of the students' ability to control themselves, amounting to 124 people in middle category with a frequency of 82 students $(66.13 \%)$ and a small self-control ability of other students that are in the low category with frequency 28 students $(22.58 \%)$, and high category with a frequency of 14 students $(11.29 \%)$.

\section{Peer Conformity $\left(\mathrm{X}_{2}\right)$}

Conformity peers at the high category with a frequency of 85 students $(68.55 \%)$ and most other peer conformity friends in middle category with a frequency of 32 students $(25.81 \%)$ and very high-frequency category 7 students (5.64\%).

\section{Smoking Behavior}

Most students smoking behavior of students at the high category with a frequency of 80 students $(64.52 \%)$ and others are in the category with a frequency of 23 students (18.55\%) and very high-frequency category 82 students 21 (16.94\%).

\section{Testing Requirements Analysis Data}

Test requirements analysis undertaken in this study is a test for normality, linearity test, and a test multicollinearity. Normality test results showed normal distribution of data. The next of the linearity test results are known data are expressed linearly. Then, multicolinearity test results showed no multicollinearity

\section{Hypothesis: Relationship Self-control Control and Peer Conformity Peer with Smoking Behavior}

The results of the analysis of the relationship of self-control and conformity peers in smoking behavior, the R-value of 0.846 which indicates the coefficient of multiple regression between selfcontrol and conformity peers in smoking behavior, with a significant level of 0.000 , R Square (R2) of 0.716 , this means $71,6 \%$ of high or low variation smoking behavior can be explained jointly by selfcontrol and conformity peers, while the remaining $28.4 \%$ is explained by other variables.

\section{Discussion}

\section{Self-control}

The results of data analysis showed that the overall average self-control students in middle category. This means that the control of the student is not maximized. Self-control students who are still in middle category would need to be given control of ourselves as the ability to minimize occur adverse behaviors of students (Ghufron, 2014; Pranoto, Y. K. S. 2017).

Next, look in detail the results of the data analysis, self-control students in the indicator informationcontrol had the highest percentage that is equal to $59.35 \%$. The lowest percentage was the indicator of the ability to obtain information with a percentage of $54.48 \%$, lower than any other indicator, although the overall percentage of each indicator is not too much different. 
The highest percentage of information control indicator shows that there are still some students who have not been able to take the positive things from the opinions and advice of others. Associated with the ability to obtain information, research results Wilfried entitled "consciousness and cognitive control", found that the processing of information related to the awareness of the situation, a person control his behavior if he knew the reason, and as a result do (Wilfried, K. 2012; Shea, N., Boldt, A., Bang, D., Yeung, N., Heyes, C., \& Frith, CD 2014).

Conversely, the lowest percentage in the indicator of the ability to obtain information showing that students are less careful in determining the attitude and lack of ability to control himself. Low self-control tend to have an attitude that impulsiveness, insensitivity, like risk, narrow-minded, and have a tendency sizable (Wikstrom \& Treiber, 2007; Masitah, M., \& Minauli, I. 2017).

Self-control can be regarded as in controlling the activity patterns of thought and behavior, before deciding to act. Controlling behavior implies, is to do the considerations before deciding anything in the act. The higher a person's self control, the more intense the possibility that the control of behavior. Low self-control will cause a person more susceptible to impulsive behavior, insensitivity, likes to take risks and have a tendency substantially to something (Vitasari, I. 2016;Ashary, Y., \& Fatimah, J. M. 2016).

\section{Peer Conformity}

Results showed an overall average shows that conformity peers at the high category. The high percentage of the indicator group agreement shows that members of the group felt compelled to follow the group's decision and the lack of courage of expression in the group. Teenagers who have entered into the peer group will feel the pressure, so that the adolescent conform to the norms and expectations of the group (Soetjiningsih 2010; Herlyana, E. 2014. Fauziah, S., \& Mutiah, D. 2015. Hidayatullah, R. 2017).

The peer group becomes very meaningful and influential in the social life of a teenager, as a place to learn social abilities and take on various roles. Teens become very dependent on their peers, but does not mean they agree with every decision peer groups. Certain reasons teens follow the decision making groups such as: fear isolated, worry does not have any friends, and do not dare to oppose the group's decision. Teenagers will do anything, to be included as members of the group including the acts of rogue (Santrock, 2003;Malihah, E. 2014).

Conversely, the lowest percentage is the indicator of confidence in the group, it shows that students do not fully trust the group. One aspect of the conformity is normative aspects. This aspect was also referred to the social aspect of the normative reveal any differences or adjustments perceptions, beliefs and actions of individuals as a result of the fulfillment of the award positive group, in order to obtain approval, liked, and avoid rejection (Baron \& Byrne 2005;Budiani, W).

Based on the research results and the exposure that has been described, it can be deduced that the conformity peers due to the pressure of a real or imagined students, although fundamentally at odds with the wishes of the students, but the tendency to follow the same behavior persists, seen from the results of studies showing conformity compliance at the high category, compared with the acceptance of conformity which are in the medium category. The cause of the high conformity compliance, due to the inability of students to conflict with what the group does.

\section{Smoking Behavior}

The results of data analysis showed that the overall average smoking behavior of students at the high category. The results of data analysis showed that the highest percentage is in the length indicator of smoke in certain circumstances with a percentage of $77.44 \%$, and the indicators of social activity with a percentage of $77.26 \%$, while the lowest percentage is the indicator of demand of $74.24 \%$. Old smoke is influenced by many things, one of the aspects that influence the function of smoking in everyday life. Function smoke can describe the feelings experienced by smokers, 
such as positive or negative feelings. Positive feelings such as experiencing feelings of calm and comfortable when taking cigarettes (Nasution, 2007).

Some students enjoy the tranquility and comfort by eating a cigarette in a long time, it can be seen on the i. Old person smokes influenced by psychological factors in smoking. That is, the psychological state of a person determines the length of a person smokes (Triyanti 2006; Cohrs, S., Rodenbeck, A., Riemann, D., Szagun, B., Jaehne, A., Brinkmeyer, J., \& Dahmen, N. 2014).

On social activity indicator, visible students find it easier to adjust to his friends at the time of smoking together. That is, the social environment influence the smoking behavior of adolescents, teenagers tend to mimic the behavior of others. It became one of the determinants of smoking behavior. Smoking was shown to follow the smoking habit, the identification of other smokers, and determine the person's self image (Smet, 1994).

On both indicators of consumption of cigarettes per day, can be seen in Table 6 .

Table 1. Total Consumption of Cigarettes Per Day

\begin{tabular}{ccc}
\hline Consumption of Cigarettes Per day & Frequency & $\%$ \\
\hline 1 - 10 cigarettes per day & 19 & 15.32 \\
$11-20$ cigarettes per day & 58 & 46.77 \\
$21-30$ cigarettes per day & 39 & 31.45 \\
$\geq 30$ cigarettes per day & 8 & 6.45 \\
Amount & 124 & 100 \\
\hline
\end{tabular}

Smoking behavior is based on the intensity of the smoke, divided by the number of cigarettes smoked each day, among other things: a very heavy smoker, the cigarette smokers who consume very often that is smoked over 30 cigarettes per day, heavy smokers that smokers who spend 21-30 cigarettes per day, moderate smokers of cigarettes that smokers who consume 11-20 cigarettes per day, and light smokers who consume cigarettes that smokers rarely is 1-10 cigarettes per day (Mu'tadin, 2002).

Referring to the above classification of smoking intensity, showing that the students included a very heavy smoker as much as 8 student, heavy smokers were 39 students, smokers were as many as 58 students, and are included in the category of light smokers were 19 students.

\section{Relationship Self-Control and Conformity Peer to Smoking Behavior}

The results showed that there is a significant relationship between self-control and conformity peers together with smoking behavior. The discovery was made based on sequence analysis of the data suggests that the contribution of self-control and conformity peers, together against the smoking behavior of $71.6 \%$. That is, the lack of ability to control themselves and conformity negative peers, are the factors that contribute to the onset of smoking behavior of students.

The smoking habit is influenced by factors other than from within oneself, is also influenced by environmental factors, environmental factors could have on the factor family, home or even milieu. Another factor, which may lead to smoking behavior is the influence of advertising (Komalasari \& Helmi, 2008).

Back to the results showed that the relationship between self-control and conformity peers together with smoking behavior, contributing to a huge increase in comparison to donations alone. This means that students have self-control in middle category and along with the high conformity peers, so the impact on the high smoking behavior of students. 


\section{Conclusion}

Based on the findings and discussion of results, it can be concluded that on average the control in middle category, conformity to peer at the high category, and smoking behavior at the high category. There is a significant relationship between self-control and conformity peers together with smoking behavior. That is, the level of smoking behavior is not only influenced by one variable (self-control or conformity to peers), but influenced jointly by self-control and conformity peers.

\section{References}

Acarli, D. S. (2014). An Examination of High School Students, Smoking Behavior by Using the Teory of Planned Behavior. Journal of Baltic Science Education, 13 (4) 497-507.

Ashary, Y., \& Fatimah, J. M. (2016). Pengendalian Perilaku Emosional Anak Tk melalui Komunikasi antara Guru dengan Orang Tua di Kec. Biringkanaya Kota Makassar. KAREBA: Jurnal Ilmu Komunikasi, 4(4), 415-434.

Asmani, M. J. (2012). Kiat Mengatasi Kenakalan Remaja di Sekolah. Jogjakarta: Buku Biru.

Aula, L. E. (2010). Stop Merokok. Yogyakarta: Garailmu.

Baron, R. A dan Byrne. (2005). Psikologi Sosial Jilid 2. Edisi Kesepuluh. Jakarta: Erlangga.

Beyers, W., \& Luyckx, K. (2016). Ruminative Exploration and Reconsideration of Commitment as Risk Factors for Suboptimal Identity Development in Adolescence and Emerging Adulthood. Journal of adolescence, 47, 169-178.

Budiani, W. Pengaruh Motivasi Konsumen dan Konformitas Kelompok terhadap Keputusan Membeli Tas Branded Imitasi(Bachelor's thesis, UIN Syarif Hidayatullah Jakarta: Fakultas Psikologi, 2015)

Cohrs, S., Rodenbeck, A., Riemann, D., Szagun, B., Jaehne, A., Brinkmeyer, J., \& Dahmen, N. (2014). Impaired Sleep Quality and Sleep Duration in Smokers Results from The German Multicenter Study on Nicotine Dependence. Addiction Biology, 19 (3), 486-496.

Daravill W, Powell K. (2002). The Puberty Book(Panduan Untuk Remaja). Jakarta: Gramedia.

Faridah, F. (2015). Analisis Faktor-faktor Penyebab Perilaku Merokok Remaja di SMK " $X$ " Surakarta. Jurnal Kesehatan Masyarakat (e-Journal), 3 (3), 887-897.

Fauziah, S., \& Mutiah, D. (2015). Pengaruh Trait Kepribadian Big Five dan Konformitas Teman Sebaya terhadap Agresivitas Anak Punk di Jabodetabek. Raheema, 2 (2).

Ghufron. M. N. (2014). Teori-teori Psikologi. Yogyakarta: Ar-Ruzz Media.

Halim, N. A. B. A., Masyarakat, B. I. K., \& Komunitas, D. I. K. (2013). Faktor-Faktor Psikologis yang Menentukan Perilaku Merokok pada Mahasiswi Kedokteran di Universitas Hasanuddin tahun 2013.

Handayani, E. R., \& Rozali, Y. A. (2015). Hubungan Konsep Diri dengan Konformitas Anggota Komunitas X yang Merokok. Jurnal Psikologi, 13 (02).

Herlyana, E. (2014). Fenomena Coffee Shop sebagai Gejala Gaya Hidup Baru Kaum Muda. Thaqafiyyat: Jurnal Bahasa, Peradaban dan Informasi Islam, 13 (1), 187-204.

Hidayati, N. W. (2016). Hubungan Harga Diri dan Konformitas Teman Sebaya dengan Kenakalan Remaja. Jurnal Penelitian Pendidikan Indonesia, 1(2).

Hidayatullah, R. (2017). Hubungan Konformitas Teman Sebaya dengan Perilaku Seksual pada Pelajar di Kota Bukittinggi. Jurnal RAP, 5 (1), 82-91.

Kemenkes RI. (2015). Profil Kesehatan Indonesia Tahun 2014. Jakarta: Kemenkes RI

Kurniafitri, D., \& Asriwandari, H. (2015). Perilaku merokok pada perempuan di perkotaan (studi kasus mahasiswi di Kota Pekanbaru). Jurnal Online Mahasiswa (JOM) Bidang Ilmu Sosial dan Ilmu Politik, 2 (2), 1-15.

Kurniawan, S., \& Rois, A. M. M. (2009). Tawuran, Prasangka terhadap Kelompok Siswa Sekolah lain, serta Konformitas pada Kelompok Teman Sebaya. 
Lubis, E. E. (2015). Fenomena Perempuan Perokok di Pekanbaru. Jurnal Online Mahasiswa (JOM) Bidang Ilmu Sosial dan Ilmu Politik, 3 (1), 1-15.

Malihah, E. (2014, June). Kenakalan Remaja Akibat Kelompok Pertemanan Siswa. In Forum Ilmu Sosial $41(1)$

Mariyati, L. I. (2014). Pelatihan Manajemen Diri dengan Pendekatan Choice Theory untuk Menurunkan Kecenderungan Merokok pada Remaja. Jurnal Ilmiah Psikologi Terapan, 2(1), 103114.

Masitah, M., \& Minauli, I. (2017). Hubungan Kontrol Diri dan Iklim Sekolah dengan Perilaku Bullying. Analitika, 4 (2), 69-77.

Mu'tadin, Z. (2002). Panduan bagi Para Perokok. Jakarta: Hipokrates.

Myers, D. G. (2012). Psikologi Sosial Jilid 2. Jakarta: Salemba Humanika.

Pranoto, Y. K. S. (2017). Kecerdasan Moral Anak Usia Prasekolah. Edukasi, 2 (1).

Priantoro, A. 2011. Hubungan antara Konformitas Kelompok dengan Perilaku Agresif pada Siswa-siswi Kelas 1 Reguler SMU Islam PB Sudirman. Jakarta. Universitas Gunadarma: Fakultas Psikologi.

Rachmalia \& Indriyana, P. (2011). Perbandingan Persepsi Siswa SMA Negeri Adidarma Banda Aceh tentang Dukungan Keluarga dan Teman Sebaya terhadap Perilaku Merokok. Idea Nursing Journal. 2 (2) 111-123.

Ramdani, A. (2016). Hubungan antara Kontrol Diri dan Kepatuhan terhadap Aturan Sekolah dengan Perilaku Merokok Siswa SMK Negeri 3 Tanah Grogot. E-journal psikologi.fisip-unmul.ac.id. 4 (3) 574-582.

Riset Kesehatan Dasar. (2013). Peningkatan Perokok Usia Remaja. Jakarta: Badan Litbangkes, Depkes RI.

Santrock, J. W. (2003). Perkembangan Remaja. Jakarta: Erlangga.

Saputro, B. M., \& Soeharto, T. N. E. D. (2012). Hubungan antara Konformitas Terhadap Teman Sebaya dengan Kecenderungan Kenakalan pada Remaja.

Shea, N, Boldt, A., Bang, D., Yeung, N., Heyes, C., \& Frith, C. D. (2014). Supra Personal Cognitive Control and Metacognition. Trends in Cognitive Sciences, 18 (4), 186-193.

Smet, B. (1994). Psikologi Kesehatan. Jakarta: PT. Gramedia Widiasarana Indonesia.

Soetjiningsih. (2010) . Tumbuh Kembang Remaja dan Permasalahannya. Jakarta: Sagung Seto.

Yulfitri, F., Marjohan, M., \& Sano, A. (2014). Konformitas Internalisasi Siswa terhadap Peraturan Sekolah dan Implikasinya dalam Layanan Bimbingan dan Konseling. Jurnal Konseling dan Pendidikan, 2 (1), 36-41.

Vitasari, I. (2016). Kejenuhan Belajar Ditinjau dari Kesepian dan Kontrol Diri Siswa Kelas Xi Sman 9 Yogyakarta. Jurnal Riset Mahasiswa Bimbingan Dan Konseling, 5(7)

Wilfried, K. (2012). Consciousness and Cognitive Control. Journal Advances in Cognitive Psychology, 8 (1) $9-18$. 